\title{
Citizenship, Social Change, and Education
}

Mitja SARDoč ${ }^{1}$

$\approx$ In recent decades, discussions regarding citizenship and citizenship education have evolved from a marginal issue in political philosophy and the philosophy of education to one of the most pressing topics in contemporary discussions about the civic aims of public schooling. The place and contribution of citizenship education in public schools have become central points of discussion and debate in terms of theory, research, policy, and practice. Yet, existing conceptions of citizenship education differ considerably over various issues, including the basic motivational impulses associated with the civic aims of public education. In particular, the recent upsurge of phenomena as diverse as hate speech, populism, the shrinking civic space, radicalisation, and violent extremism have shifted the main justificatory impulse from consequentialist to urgency-based arguments. This shift of emphasis has had some unreflected consequences related to the justification for citizenship education in public schools. The central purpose of this article is to expound on the two main impulses associated with the civic aims of public schools and their interrelationship with social changes. The main part contrasts these two opposing motivational impulses associated with the justification of citizenship education. Each of the two impulses is presented and then clarified with an example to shed light on the basic justificatory procedure associated with it. The concluding part of this paper sketches the most distinctive challenges of the alternative conception of justifying citizenship education and its interplay with social change.

Keywords: citizenship education, social change, education reform, radicalisation, violent extremism 


\section{Državljanstvo, družbene spremembe in izobraževanje}

Mitja SARDoč

$\propto$ V zadnjih nekaj desetletjih so se razprave o državljanstvu in državljanski vzgoji iz obrobja politične filozofije in filozofije vzgoje premestile v samo središče sodobnih razprav o državljanskih ciljih javnega šolanja. Vloga in pomen državljanske vzgoje $\mathrm{v}$ javnih šolah sta postala osrednji točki razprav $\mathrm{z}$ vidika teorije in raziskav pa tudi politike in pedagoške prakse. Kljub temu pa se obstoječa pojmovanja državljanske vzgoje precej razlikujejo glede vrste različnih vprašanj, npr. z osnovnimi motivacijskimi vzgibi, povezanimi z državljanskimi cilji javnega šolanja. Vzpon tako raznolikih pojavov, kot so: sovražni govor, populizem, krčenje državljanskega prostora, radikalizacija in nasilni ekstremizem, je glavni utemeljitveni vzgib, povezan z državljansko vzgojo, preusmeril od konsekvencialističnih argumentov $\mathrm{k}$ argumentom, ki temeljijo na nujnosti. Ta premik poudarka je imel nekaj nepremišljenih posledic, povezanih z utemeljitvijo državljanske vzgoje v javnih šolah. Osrednji namen tega članka je pojasniti dva glavna impulza, povezana $z$ državljanskimi cilji javnega šolanja, in njuno povezanost z družbenimi spremembami. Glavni del prispevka analizira vsakega izmed obeh motivacijskih impulzov, povezanih z utemeljitvijo državljanske vzgoje. Vsak izmed njiju je predstavljen in nato še pojasnjen s primerom, da se osvetli osnovni argumentacijski okvir, ki je povezan z njim. Sklepni del prispevka prikaže najznačilnejše izzive alternativnega modela utemeljitve državljanske vzgoje in njegove povezanosti z družbenimi spremembami.

Ključne besede: državljanska vzgoja, družbene spremembe, šolska reforma, radikalizacija, nasilni ekstremizem 


\section{Citizenship, social change. and education: some preliminary considerations ${ }^{2}$}

The debates over the status, scope. and justification of citizenship education in a plurally diverse polity have taken place across a range of academic disciplines. including political philosophy (Ben-Porath, 2006; Galston, 2002; Gutmann, 1995, 1999; Kymlicka, 1995; 2001; Levinson, 1999; MacMullen, 2007; Macedo, 2000; Reich, 2002; Rawls, 1993; Rosenblum, 2000; Tamir, 1995; Tomasi, 2001), political theory (Crick, 2000; Miller, 2000; Spinner-Halev, 1994), philosophy of education (Archard, 2003; Callan, 1997; Clayton, 2006; Enslin \& White, 2002; Feinberg, 1998; Haydon, 2003; McLaughlin, 1992; 2000; 2003; Sardoč, 2010), education policy and curriculum studies (Lockyer et al., 2003), sociology of education (Arnot \& Dillabough, 2000; Beck, 1998; Hahn, 1998; Parker, 2003) and other disciplines within the broader field of the social sciences and education (Cogan \& Derricot, 1998; Kiwan, 2007; Starkey \& Osler, 2005; etc.).

An interesting trend is observable in these discussions. On the one hand, there has been little disagreement over the centrality of citizenship as 'a political conception of the person' (Rawls, 1993) and the role of public education in the project of educating citizens as fully cooperating members of a polity. In fact, 'the nature of citizenship and the education suited to its realisation', writes Eamonn Callan, 'have traditionally figured among the basic questions of normative political theory' (Callan, 2004, p. 71). As Meira Levinson accentuates,

[c]ivic education is crucial in a liberal state, I suggest, because no matter what institutions and freedoms are built into the basic structure and constitution of the state, their realisation will always depend on the character and commitments of its citizens [...]. (Levinson, 1999, pp. 101-102).

As has been rightly emphasised by scholars who identify either as liberals, republicans, social conservatives and multiculturalists, the stability of a plurally diverse polity does not depend exclusively on the justice of its basic institutional framework but also on the virtues, dispositions and active engagement of its citizens and in the associative network of civil society (Dagger, 1997; Galston, 1991; Macedo, 1990; White, 1996). Creating virtuous citizens, Callan points out, is as necessary an undertaking in a liberal democracy as it is under any other constitution' (Callan, 1997, p. 3). In fact, without citizens who are equipped with civic virtues and other dispositions, writes William Galston, 'the ability of liberal societies to function successfully progressively diminishes' (Galston, 1991, p. 220).

2 Part of this research article is based on Sardoč (2012). 
On the other hand, despite the convergence of opinion on the centrality of public education in educating students as fully cooperating members of a polity, citizenship education remains a strategic battleground between advocates of divergent traditions of political thought, as well as between scholars sharing the same normative outlook. For example, as John Tomasi emphasises,

[...] civic education has proven one of the most hotly contested terrains on which proponents of political liberalism have sought to differentiate their view from the various forms of ethical or comprehensive liberalism they seek to displace. (Tomasi, 2002, p. 196)

Interestingly enough, the 1990s have arguably been among the most productive periods for theorising about citizenship, social change and education, as 1989 stands out as 'Year One' on the calendar of contemporary social and political changes (Kymlicka, 1989; Taylor, 1994; Young, 1990). The fall of the Berlin Wall and 'France's headscarf affair' together with the 'Satanic Verses controversy' on the other, both taking place just a few weeks from one another. In particular, the collapse of undemocratic forms of government around the globe has had an inspiring influence on the overall positive impact of democratisation and the spread of the culture of human rights in formerly oppressive and undemocratic regimes. In contrast, the rise of xenophobic nationalism and religious fundamentalism in different regions of the world (e.g., the conflicts in the former Yugoslavia) together with a decline in social, civic and associational life in well-established liberal and democratic countries (Macedo, 2005; Putnam, 200o) have had a negative effect on the stability of our plurally diverse societies.

In particular, social and political changes have influenced the development of discussions over the foundations, nature, and value of citizenship and the discussions on the status, scope, and justification of citizenship education in a plurally diverse polity. In fact, there has been a serious concern both among scholars and policymakers over some of the most pressing challenges facing contemporary democratic societies, including the overall distrust among citizens in the institutional framework of a liberal and democratic polity, the increasing 'democratic deficit' and the resulting criticism that the rights-based conception of citizenship may lack the resources with which to respond to the phenomena that challenge the very foundations of diverse contemporary societies, such as hate speech, populism, the shrinking civic space as well as radicalisation and violent extremism (Sardoč et al., 2021). These social changes (and the associated challenges) have raised both theoretical controversies and practical problems, thus requiring a reconsideration of the civic aims of public education. 
At the theoretical level, the civic aims of public education have remained a minefield of tensions, problems, and challenges that reverberate not only in scholarly discussions but have also come to play a central part in educational practice and everyday school life. For example, the introduction of citizenship education as part of the statutory school curriculum (e.g., in England with the 'Crick Report', in Slovenia as part of the comprehensive school reform in the 1990s) together with various other initiatives by major international stakeholders (e.g., the IEA ICCS survey $^{3}$ or the Council of Europe's 'Education for Democratic Citizenship'4 initiative) have been a testament on the importance of civic aims for public education.

The central purpose of the present article is to expound on the two main impulses associated with the civic aims of public schools and their interrelationship with social changes. The main part contrasts these two opposing motivational impulses associated with the justification of citizenship education. Each of the two impulses is presented and then clarified with an example to shed light on the basic justificatory procedure associated with it. The concluding part of this paper sketches the most distinctive challenges of the alternative conception of justifying citizenship education and its interplay with social change.

\section{The functionalist impulse}

As a broadly philosophical problem and as a matter of educational policy, educating citizens as fully cooperating members of a polity is part of a more general problem about the civic unity, social cohesion and stability of a plurally diverse polity. As citizens, writes Walter Feinberg (1998), 'Our primary obligation is to maintain the institutions, practices, and values that provide the conditions for a useful and productive life for all other citizens [...]' (p. 211). In the Introduction to Political Liberalism (1993), John Rawls poses the problem of stability of a diverse democratic society as follows:

How is it possible that there may exist over time a stable and just society of free and equal citizens profoundly divided by reasonable though incompatible religious, philosophical and moral doctrines? (p. 4)

Part of the answer to the question of what citizenship education in a plurally diverse polity requires is primarily contextual since what constitutes

3 The IEA ICCS Survey 'is the largest international, and only dedicated study of civic and citizenship education. It makes a substantial contribution to our knowledge about civic and citizenship education in schools and our understanding of how diverse countries prepare their young people for citizenship' (Source: IEA ICCS https://www.iea.nl/studies/iea/iccs).

4 For a detailed presentation of the Council of Europes work on education for democratic citizenship and human rights education, see https://www.coe.int/en/web/edc/home?desktop=true 
citizenship and what constitutes 'good' citizenship is not exclusively a theoretical endeavour. Any 'regime' - a liberal democratic one included - needs the conditions necessary to promote common principles and shared public values and maintain its basic institutional framework. As Judith Shklar (1989) emphasises succinctly, '[g]ood citizenship simply is not separable from the sort of society in which it functions' (p. 12). Any political 'regime', then, has its own institutional framework that aims to perpetuate common principles and shared public values that aim to support it. The locus classicus for the thesis that public education is central to the cultivation of beliefs, values and virtues that in turn support its basic institutional framework is to be found in the introductory paragraph of Book VIII of Aristotle's Politics. I quote him here at some length:

The citizen should be moulded to suit the form of government under which he lives. For each government has a peculiar character which originally formed and which continues to preserve it. The character of democracy creates democracy, and the character of oligarchy creates oligarchy; and always the better the character, the better the government. (1999, p. 195)

William Galston eloquently summarises the classical Aristotelian justification for citizenship education, '[s]ince Plato and Aristotle first discussed the matter, it has been clear that citizenship education is relative to regime type' (Galston, 2001, p. 217). As Harry Brighouse (2000) rightly emphasises, standard arguments for citizenship education:

[...] often start with the need to maintain the state in some prescribed form, and then prescribe education of a certain kind to cultivate in children the characters likely to stabilise that state (p. 71).

Citizenship education, writes Galston (2006), 'aims towards practice and is relative to specific regime-types and particular communities' (p. 331). Given the centrality of public education in contemporary societies, attitudes to citizenship education are dependent on the particular conception of a citizen. John Tomasi (2001) advances an even firmer connection between the virtues of citizens and a regime type:

Different kinds of attitudes and activities are required of people as citizens within different types of regimes. Norms of good citizen conduct vary, for example, across theocratic, fascist, communist, and liberal regimes. But in every case, the norms applicable to people as citizens are given in terms of each regime's underlying ideal of societal success (p. 57).

A basic aim of citizenship education in a plurally diverse polity, then, includes the promotion of shared public values that will create a common ground 
between different ethnocultural, religious, and cultural identities of its citizens as well as contribute to the maintenance of the basic institutional framework, including public education, that provides the conditions for a stable, ethical environment for all members of a political community. As Walter Feinberg (1998) rightly emphasises, public schools in contemporary liberal democratic societies perform two critical functions:

First, in complex societies they advance public safety and development by socialising children into the general rules of the society, by establishing in them a commitment to the safety and well-being of their fellow members, and by providing them with the skills to advance both their individual and the social interest. Second, schools are critical instruments for reproducing the basic values of liberal society itself and of assuring its continuation across different generations (p. 9).

In a plurally diverse polity, citizenship education shares with other models of citizenship education the requirement of stability, the requirement of civic unity, and the requirement of sustainability. These 'generic' requirements any model of citizenship education needs to perform in order to meet the required goals of civic reproduction have been most visible in educational reforms following post-1989 social and political changes.

\section{A genealogy of citizenship education in Slovenia: main policy orientations}

An example of this basic motivational impulse sketched above has been the introduction of citizenship education in Slovene public schools that was part of the educational reform in the 1990s. Social and political changes in Slovenia in the second half of the 1980s, together with the proclamation of independence in 1991, had an inspiring influence both on the overall positive impact of democratisation and the spread of the culture of human rights as well as a decisive impact on the status, scope, and justification of citizenship education in public schools. One of the most important curricular changes was the abolition of two explicit ideological school subjects closely associated with socialism. Immediately after the democratisation and the independence of Slovenia in 1991, the Self management and the basics of Marxism school subject was withdrawn from the curriculum. At the elementary education level, the Social and moral education school was replaced with the experimental school subject Ethics and society. ${ }^{5}$

5 For a detailed presentation of citizenship education implementation in Slovenia, see Šimenc and Sardoč (2016). 
Moreover, part of the reform of public education that took place between 1996 and 1999 was the introduction of the school subject entitled Citizenship education and ethics. In fact, the entire reform of the public school system in Slovenia - according to the White Paper - was based on the common European heritage of political, cultural and moral values manifested in human rights, a state governed by the rule of law, pluralistic democracy, tolerance and solidarity. The Starting Points for Curriculum Reform (1995) which formed one of the most important documents of the educational reform of Slovene public education, emphasised that the aims of public education are:

- $\quad$ individuals and their development (as cultural, creative, and working social beings aware of their environment),

- freedom and responsibility of those who participate in the education of students, parents,

- $\quad$ equal opportunities in education for all individuals and different social groups,

- $\quad$ tolerance and solidarity as contents and as a way of educating, national identity and openness to international cooperation.

Moreover, the White Paper on Education in Slovenia (1996) and the educational legislation which came into force in 1996, both of which set systemic, normative and legislative framework of public education, emphasise that the basic aims of public education in Slovenia take into account several recommendations by leading international organisations in the field of citizenship education, including those of the Council of Europe, UNESCO, among others. Two civic aims, in particular, have been emphasised in the White Paper on Education in the Republic of Slovenia: 1) civic literacy and the knowledge of human rights; 2) education for and participation in democratic processes (Krek, 1996, pp. 44-48). Furthermore, Article 2 of the Elementary School Act states that the main aims of elementary education in Slovenia are:

- developing consciousness of citizenship and national identity, knowledge about Slovene history and its culture,

- $\quad$ educating for general cultural and civilisational values which originate in the European tradition,

- $\quad$ educating for mutual tolerance, respect for differences and cooperating with others, respect for human rights and basic liberties, thus developing abilities required for living in a democratic society (Elementary School Act, art. 2).

As this example clarifies, the social changes of the 1990s in Slovenia (and several other countries that were on the path of democratisation) have had a 
twofold transformative influence on the civic aims of public education. The first change has marked a transition in the understanding of citizenship as a shared political status associated with free and equal membership in a political community. The second and related change marks a transition from a purely proceduralist understanding of the functioning of a polity and its basic institutional framework to an approach that emphasises the role and the importance of civic virtues. In this sense, civics and citizenship education is part of a more general problem about the stability of a plurally diverse polity and maintaining its basic institutional framework.

\section{The compensatory impulse}

Alongside the consequentialist justification associated with the 'functionalist' impulse sketched above, contemporary scholarship on citizenship education tends to advance another way of justifying the civic agenda of public schools. In recent years, there has been a departure from the functionalist justification of citizenship education towards alarmist proclamations founded on urgency-based justifications that question the vitality of our democratic institutional framework. The prevalence of alarmist proclamations about the civic erosion and social fragmentation of our societies poses a range of separate problems at the level of justification, as according to this interpretation, the primary role of citizenship education in public schools is not constitutive but primarily compensatory in nature.

Urgency-based arguments associated with alarmist proclamations have started to arise primarily due to a set of phenomena that challenge the very core of the liberal and democratic institutional framework we inhabit, including hate speech (Waldron, 2012), fake news, populism (Galston, 2018), the shrinking civic space (Deželan et al., 2020) as well as radicalisation and violent extremism (Sardoč et al., 2021). On this interpretation, the social unity of contemporary societies has been seriously undermined due to several 'dysfunctional' phenomena, which are supposed to have corrosive effects on shared public values of liberal and democratic societies. At the same time, the stability of contemporary pluralist democracies has been challenged by a decreasing level of civic participation and a general carelessness about community involvement and the common good (Sandel, 2020).

Another important 'urgency-based' justification has been advanced under the banner of securitisation. For example, post-9/11 scholarship on radicalisation and violent extremism has been built around the weaponisation of fear. Despite the consensus that radicalisation and violent extremism represent 
a major challenge to the political, economic, and social security of contemporary societies, the weaponisation of fear leads to the 'social construction of risk' (Githens-Mazer, 2012, p. 557). In fact, the transformation of otherwise completely legitimate and largely unproblematic social phenomena into a security risk is one of the key challenges the strategy of securitisation as a process of social construction of security faces (Floyd, 2019).

\section{Conclusion: implications for future research}

Ever since Antiquity, the role of public education in general and of citizenship education, in particular, has been to support the polity and its basic institutional framework by creating a virtuous citizenry. As exemplified by Aristotle (1999), the classical understanding of citizenship education linked the ideal of a citizen as a fully cooperating member of a polity with a particular model of a political community. In contrast, contemporary arguments for the necessity of citizenship education depart significantly from this classical understanding of the aims of educating citizens as its different forms of justification rest on the alleged failure of our shared institutions to educate citizens as fully cooperating members of a polity.

The two motivational impulses associated with citizenship education sketched above are both primarily of purpose: why should public schools engage in citizenship education? A straightforward answer is basically uncontroversial and contains two separate propositions. First, as the functionalist impulse makes clear, any polity needs to create and support the conditions of its stability and the maintenance of its basic institutional framework. Second, due to a range of contemporary challenges (e.g., populism, hate speech, radicalisation and violent extremism, diversity, civic disengagement), the function of citizenship education is primarily compensatory in nature. Nevertheless, the compensatory impulse delimits the scope of citizenship education as exclusively restorative. In particular, the consequentialist arguments sketched above maintain that citizenship education is primarily a prerequisite of stability (or security in the case of radicalisation and violent extremism). Despite a prima facie attractiveness of urgency-based justifications, its very strength has become its most pressing liability due to the instrumentalisation component. 


\section{References}

Archard, D. (2003). Citizenship education and multiculturalism. In A. Lockyer, B. Crick, \& J. Annette (Eds.), Education for democratic citizenship: Issues of theory and practice (pp. 89-102). Ashgate. Aristotle (1999). The politics and the constitution of Athens. Cambridge University Press.

Arnot, M., \& Dillabough, J.-A. (Eds.) (200o). Challenging democracy: International perspectives on gender, education and citizenship. Routledge/Falmer.

Beck, J. (1998). Morality and citizenship in education. Cassell.

Ben-Porath, S. R. (2006). Citizenship under fire: Democratic education in times of conflict. Princeton University Press.

Brighouse, H. (2000). School choice and social justice. Oxford University Press.

Callan, E. (1997). Creating citizens: Political education in a liberal democracy. Oxford University Press.

Callan, E. (2004). Citizenship and education. Annual Review of Political Science, 7, 71-90.

Clayton, M. (2006). Justice and legitimacy in upbringing. Oxford University Press.

Cogan, J., \& Derricot, R. (1998). Citizenship for the $21^{\text {st }}$ century. Kogan Page.

Crick, B. (2000). Essays on citizenship. Continuum.

Dagger, R. (1997). Civic virtues: Rights, citizenship and republican liberalism. Oxford University Press.

Deželan, T., Sardoč, M., \& Laker, J. (2020). Safeguarding civic space for young people in Europe. European Youth Forum. https:// www.youthforum.org/safeguarding-civic-space-young-people-europe

Enslin, P. (2003). Citizenship education in post-Apartheid South Africa. Cambridge Journal of

Education, 33(1), 73-83.

Feinberg, W. (1998). Common schools/uncommon identities: National unity \& cultural difference. Yale University Press.

Floyd, R. (2019). The morality of security: A theory of just securitization. Cambridge University Press.

Galston, W. A. (1991). Liberal purposes: Goods, virtues, and diversity in the liberal state. Cambridge

University Press.

Galston, W. A. (2001). Political knowledge, political engagement, and civic education. Annual Review of Political Science, 4, 217-234.

Galston, W. A. (2002). Liberal pluralism: The implications of value pluralism for political theory and practice. Cambridge University Press.

Galston, W. A. (2006). Signs of progress: The debate over civic education: Theory and research in education, 4(3), 329-337.

Galston, W. A. (2018). Anti-pluralism: The populist threat to liberal democracy. New Yale University Press.

Githens-Mazer, J. (2012). The rhetoric and reality: Radicalisation and political discourse.

International Political Science Review, 33(5), 556-567.

Gutmann, A. (1995). Civic education and social diversity. Ethics, 105(3), 557-579.

Hahn, C. L. (1998). Becoming political: Comparative perspectives on citizenship education. State University of New York Press. 
Haydon, G. (2003). Aims in citizenship education: Responsibility, identity, inclusion. In A. Lockyer,

B. Crick, \& J. Annette (Eds.), Education for democratic citizenship: Issues of theory and practice (pp. 78-88). Ashgate.

Kiwan, D. (2007). Education for inclusive citizenship. Routledge.

Kovačić, M., \& Horvat, M. (Eds.) (2016). Od podanika do građana: razvoj građanske kompetencije mladih. Institut za društvena istraživanja: GONG.

Krek, J. [Ed. ] (1996). Bela knjiga o vzgoji in izobraževanju v Republiki Sloveniji [White paper on education of Republic of Slovenia]. Ministrstvo za šolstvo in šport.

Kymlicka, W. (1989). Liberalism, community and culture. Clarendon Press.

Kymlicka, W. (1995). Multicultural citizenship: A liberal theory of minority rights. Oxford University Press. Levinson, M. (1999). The demands of liberal education. Oxford University Press.

Levy, J. T. (2000). The multiculturalism of fear. Oxford University Press.

Lockyer, A., Crick, B., \& Annette, J. (Eds.) (2003). Education for democratic citizenship: Issues of theory and practice. Ashgate.

MacMullen, I. (2007). Faith in schools? Autonomy, citizenship, and religious education in the liberal state. Princeton University Press.

McLaughlin, T. H. (1992). Citizenship, diversity and education: A philosophical perspective, Journal of Moral Education, 21(3), 235-250.

McLaughlin, T. H. (200o). Citizenship education in England: The Crick Report and beyond. Journal of Philosophy of Education, 34(4), 541-570.

McLaughlin, T. H. (2003). The burdens and dilemmas of common schooling. In W. Feinberg \& K. McDonough (Eds.), Education and citizenship in liberal-Democratic societies: Teaching for cosmopolitan values and collective identities (pp. 121-156). Oxford University Press.

Macedo, S. J. (1990). Liberal virtues: Citizenship, virtue, and community in liberal constitutionalism. Oxford University Press.

Macedo, S. J. (2000). Diversity and distrust: Civic education in a multicultural democracy. Harvard University Press.

Macedo, S. J. (Ed.) (2005). Democracy at risk: How political choices undermine citizen participation, and what we can do about it. Washington Brookings Institution Press.

Miller, D. (200o). Citizenship and national identity. Polity Press.

Parker, W. C. (2003). Teaching democracy: Unity and diversity in public life. Teachers College Press.

Putnam, R. D. (200o). Bowling alone: The collapse and revival of American community. Simon \&

Schuster.

Rawls, J. (1993). Political liberalism. Columbia University Press.

Reich, R. (2002). Bridging liberalism and multiculturalism in American education. Chicago University Press.

Rosenblum, N. L. (Ed.) (200o). Obligations of citizenship and demands of faith. Princeton University Press. Sandel, M. (2020). The tyranny of merit: What's become of the common good. Penguin Press.

Sardoč, M. (Ed.) (2010). Toleration, respect and recognition in education. Wiley-Blackwell. 
Sardoč, M. (2012). Citizenship, diversity and education: an egalitarian pluralist approach (Doctoral Thesis). Institute of Education, University of London.

Sardoč, M., Coady, Coady, C. A. J, Bufacchi, V., Moghaddam, F. M., Cassam, Q., Silva, D., Miščević, N., Andrejč, G., Kodelja, Z., Vezjak, B., Peters, M. A., \& Tesar, M. (2021). Philosophy of education in a new key: On radicalization and violent extremism. Educational Philosophy and Theory. https://doi. org/10.1080/00131857.2020.1861937

Sardoč, M. (2021). The ethics of securitisation: An interview with Rita Floyd. Critical Studies on Terrorism, 14(1), 139-148. https://doi.org/10.1080/17539153.2021.1886506

Shklar, J. (1989). The liberalism of fear. In N. L. Rosenblum (Ed.), Liberalism and the moral life (pp. 21-38). Harvard University Press.

Spinner-Halev, J. (1994). The boundaries of citizenship: Race, ethnicity, and nationality in the liberal state. The Johns Hopkins University Press.

Starkey, H., \& Osler, A. (2005). Changing citizenship: Democracy and inclusion in education. Open University Press.

Šimenc, M., \& Sardoč, M. (2016). Multiple dimensions of citizenship education implementation in Slovenia. In M. Kovačić \& M. Horvat [Eds.], Od podanika do građana: razvoj građanske kompetencije mladih (pp. 187-199). Institut za društvena istraživanja: GONG.

Tamir, Y. (Ed.) (1995). Democratic education in a multicultural society. Blackwell.

Taylor, C. (1997). The politics of recognition. In A. Gutmann [Ed.], Multiculturalism: Examining the politics of recognition (pp. 25-74). Princeton University Press.

Tomasi, J. (2001). Liberalism beyond justice: Citizens, society, and the boundaries of political theory. Princeton University Press.

Waldron, J. (2012). The harm in hate speech. Harvard University Press.

White, P. \& Enslin, P. (2002). Democratic education. In N. Blake, P. Smeyers, R. Smith, \& P. Standish (Eds.), The Blackwell guide to the philosophy of education (pp. 110-125). Blackwell.

Young, I. M. (1990). Justice and the politics of difference. Princeton University Press.

\section{Biographical note}

Mitja SARdoč, $\mathrm{PhD}$, is senior research associate at the Educational Research Institute in Ljubljana (Slovenia). He is author of scholarly articles and editor of a number of journal special issues on citizenship education, multiculturalism, toleration, equality of opportunity, patriotism, radicalisation and violent extremism. He is Managing Editor of Theory and Research in Education, Editor-in-Chief of the Handbook of Patriotism (Springer) and Editor-in-Chief of The Palgrave Handbook of Toleration. Personal webpage: https://www.researchgate.net/profile/Mitja-Sardoc. 